Title: The Critical Role of Timing in Managing Intellectual Property

Author: Timothy A. Lemper

Clinical Associate Professor of Business Law

Department of Business Law \& Ethics

Kelley School of Business

Indiana University

1309 E. 10th St., Room 233

Bloomington, IN 47405

Email: tlemper@indiana.edu

Tel: 812-855-9308

Fax: 812-856-4695 
Title: $\quad$ The Critical Role of Timing in Managing Intellectual Property

Abstract: In today's environment, timing is a critical part of business strategy. Nowhere is this truer than in managing intellectual property in an increasing global marketplace. The creation and protection of intellectual property assets often depends on taking just the right legal action at just the right time, every time, over time. The consequences of failing to do so can be disastrous, but may only be felt at a later time or in other markets. The difficulty for business people lies in the fact that the time-sensitive aspects of intellectual property cannot be managed effectively by relying on intuition or resolving to see a lawyer when the need arises.

This article provides a basic primer on the critical role of timing in identifying, creating, and protecting intellectual property assets. It discusses the most common types of intellectual property — patents, copyrights, trademarks, and trade secrets—and compares the role of timing in the creation and protection of each type of asset. Most importantly, it summarizes the key issues of timing in the creation and protection of intellectual property.

Key Words: Intellectual Property, Trademarks, Copyrights, Patents, Trade Secrets, International Law 
"Think of your priorities not in terms of what activities you do, but when you do them. Timing is everything." - Dan Millman (as quoted on Thinkexist.com, n.d.).

\section{THE IMPORTANCE OF INTERNATIONAL INTELLECTUAL PROPERTY PROTECTION}

It is not difficult to imagine situations where businesses would want legal protection against unscrupulous competitors. It could be a toy company that discovers others selling copies of its toys, a restaurant that discovers a competitor using its secret recipes, a computer company that discovers competitors using its innovative technology, or a clothing manufacturer that discovers others using brand names that are eerily similar to its own. Such acts of "unfair competition" are increasingly common, and increasingly involve the protection of intangible legal rights in intellectual property—like the right to exploit one's own creativity, innovation, information, or reputation. As a result, intellectual property (IP) is increasingly becoming one of the most valuable types of assets in business.

In today's global marketplace, it is also easy to imagine how seemingly provincial problems can transcend national borders. Consider the examples discussed above: The toy company could discover that the copycat toys are being sold on an Internet website to consumers outside the U.S., or to consumers in the U.S. by a company located outside the U.S. The restaurant could be located in Detroit, Michigan, just across the river — and the border-from the restaurant in Windsor, Canada, that is using its secret recipes. Or the clothing company could find it difficult to expand into foreign markets where competitors have already begun selling clothing using the same or similar brand names. The same technology that makes it easier and more affordable for consumers to travel, ship, and shop all over the world also poses potential problems for even small businesses that may require international strategies and solutions. As a 
result, the same forces that have driven the exponential growth of IP have also spurred efforts to develop international laws to protect and enforce IP around the world.

The challenge for businesspeople is knowing how and when to take steps to obtain legal protection for their intellectual property. Even for those who prefer to leave such matters to lawyers, it is necessary to understand how to identify IP and when to take steps to protect it—if only to know when to consult a lawyer.

\section{KNOWING IP WHEN YOU SEE IT}

U.S. Supreme Court Justice Potter Stewart once observed that he may not be able to define pornography, but "I know it when I see it" (Stewart, Jacobellis v. Ohio, 1964). Intellectual property is more clearly defined in the law, but many businesspeople take a similar approach when managing IP: They are unsure of how to define it, yet certain that they can identify and protect it. As a result, IP assets often go unidentified and unprotected until it is too late. By the time the business realizes that it has an IP issue, it may already have lost its rights.

Not surprisingly then, the critical first step to managing IP is being able to identify IP in the first place. Large businesses with substantial resources can afford to employ in-house or outside legal counsel to identify and manage their IP assets for them. But owners and managers of small and medium-size businesses often must rely on their own understanding of IP to identify and protect their IP assets. While there is no substitute for the time and effort needed to develop a sophisticated understanding of intellectual property, a basic understanding of the various types of IP is a good starting place.

The term "intellectual property" actually refers to several different types of legal rights in intangible assets, but the most common in business today are patents, copyrights, trademarks, and trade secrets. The primary difference between each type lies in the substance of what each 
protects. A comprehensive discussion of each type of IP is beyond the scope of this article, but a brief summary of each type of IP can be very useful.

\section{Patents for Useful Inventions}

Patent law protects man-made inventions that are novel, serve a useful purpose, and are not obvious to people skilled in the art of the invention. (USPTO, "Patents," n.d.). To be patentable, the invention must be a process, machine, manufacture, composition of matter, business method, or a plant reproduced by asexual production ("Patentability of Inventions," 2011). In the U.S., such patents are referred to as "utility patents." U.S. law also provides for "design patents" to protect ornamental designs that are embodied in useful articles ("Patents for

Designs," 2011). In other countries, such ornamental designs are protected as a separate type of IP known as “industrial designs” (WIPO, “About Industrial Designs,” n.d.).

To be protected in a country, an invention must be patented in the country. So a person seeking a patent for an invention must file an application with the "patent office" or similar agency in the federal government in the countries where patent protection is sought. To obtain a patent on an invention in the U.S., the inventor must file an application with the U.S. Patent and Trademark Office. If the application is successful, the owner of the patent receives the legal right to prevent others from making, using, selling, offering for sale, or importing the patented invention in the country for a fixed period of time. Under the law in the U.S. and most other countries, utility patents are protected for 20 years from the filing date of the patent application. U.S. law protects design patents for 14 years from the date that the patent is issued.

Where employers hire others to perform inventive work, the employer can claim ownership of the patent rights in their inventions as "works for hire." To be safe, businesses often require employees to sign written agreements acknowledging that the business will own the patent rights in any inventions that the business hires them to create. 
It is difficult to provide a representative list of patented inventions because the range of patentable material is so broad. A large number of patented inventions today relate to areas such as computer and Internet technology, electronics, pharmaceutical drugs, chemistry, and biotechnology. But any innovation by a company or its employees could potentially be eligible for patent protection.

\section{Copyrights for Original, Creative Expression}

Copyright law protects creative expression that is original to the author, meaning that the author must not copy someone else's creative work or merely reproduce common, unoriginal elements. In the U.S., copyright only protects works that are fixed in some tangible form, such as a writing, recording, painting, carving, or other physical object. In other countries, oral works may be protected even if not fixed in some tangible form. In all countries, however, copyright does not protect abstract concepts or ideas reflected in the work-it only protects the author's particular expression or depiction of the concept or idea (e.g., a painting of Mona Lisa, not the idea for a portrait of a smiling woman).

Under international law, creative works are entitled to automatic copyright protection, without the need to comply with any legal formalities. Under U.S. law, however, the copyright in works created in the U.S. by U.S. citizens must be registered with the U.S. Copyright Office before the copyright can be enforced in U.S. courts. Registration also provides additional benefits to the copyright owner, like the ability to recover statutory damages and attorney's fees (U.S. Copyright Office, “Copyright Basics,” 2011, p. 7).

Where employers hire others to create copyrightable material, the employer can claim ownership of the copyright in those works as "works for hire." Businesses often require employees and independent contractors to sign written agreements acknowledging that the business will own the copyright in any works that the business hires them to create. 
Copyright owners have the right to use, reproduce, distribute, display or perform, import, and make derivative versions of their copyrighted works. Copyright protection for a work lasts for a minimum of 50 years under international copyright law, although the specific length of copyright protection varies by country (WIPO, Frequently Asked Questions, "What rights does copyright provide?," n.d.). In the U.S., copyright protection in a work last for the life of the author plus 70 years, except for works created as "works for hire" that are protected for either 120 years after the work is created or 95 years after the work if first made available to the public, whichever is shorter (U.S. Copyright Office, "How Long?", n.d.).

Examples of works protected by copyright include literary works such as novels, poems, plays, newspapers and computer programs; artistic works such as paintings, drawings, photographs, sculptures, films, recordings, musical compositions, and choreography; architecture; advertisements; maps; databases; and technical drawings (WIPO, "General Information," n.d.).

\section{Trademarks for Distinctive Source Indicators}

Trademark law protects the use of an element (e.g., a word, phrase, symbol, image, color or color combination, sound, product design, product packaging) that consumers recognize as identifying a particular business and/or its products or services, and distinguishing them from other business' and their products and services. Brand names are perhaps the most well known example of trademarks. Brand names function as trademarks because consumers recognize them as identifying a particular company and/or its products and services.

Every business has potential trademarks. A business's name and logos, the brand names for its products and services, its advertising slogans, the uniforms its employees wear, the distinctive features of its packaging or advertising, the domain name for its Internet website, and even the sounds, smells, and tastes of its products are all potential trademarks. For some 
companies, these trademarks are among the most valuable assets that some companies have. For example, Interbrand estimates the value of the Coca Cola brand name at more than $\$ 70$ billion in its annual ranking of the top 100 brand names in the world (Interbrand, 2011).

A person can acquire trademark rights in the U.S. by using a mark in commerce (called "common law" rights) or by obtaining a trademark registration for its mark (called "statutory rights"). In other countries, trademark rights can only be established through registration. Unlike patent and copyright, however, trademark rights continue to exist as long as the trademark owner continues to use its trademark and/or maintain its trademark registration.

Trademark rights are defined in relation to specific goods and services: A person who establishes rights in a trademark has the legal right to use the trademark in connection with the marketing and sale of particular types of goods or services. But trademark owners do not have a monopoly on the use of the words, phrases, symbols, images, colors, sounds, or other elements that comprise their trademarks. Others remain free to use such words, phrases, and other elements, so long as they do not violate the trademark owner's right to use them as a trademark in connection with the marketing and sale of particular types of products and services.

The scope of a person's trademark rights depends on the use and registration of the trademark. Where a person acquires common law trademark rights based solely on his use of a trademark, his rights will be limited to the area where he has actually used the trademark. In contrast, a person who obtains a federal registration for his mark gains the presumptive right to use his mark everywhere in the U.S., except in areas where others established trademark rights before he obtained a federal registration. Thus, trademark owners have the right to expand the use of their trademarks into other areas and markets, even if a competitor is already using a confusingly similar mark in that area, so long as the competitor began using its mark after the 
trademark owner obtained its federal registration (USPTO, "Trademark FAQs," n.d., "What are the benefits of federal trademark registration?”; WIPO, “About Trademarks,” n.d.).

Trademark rights include the right to prevent others from using the same or a similar trademark in a way that is likely to cause consumers to be confused about the source of the parties' products and services, or about the relationship between the parties. Owners of "famous" marks (i.e., marks that have acquired a very high level of nationwide fame) can also prevent others from using the same trademark for any product or service, not just the type of products and services for which the famous mark is used. Conflicts among different parties' trademark rights are resolved based on priority: Where two people use similar marks for similar goods or services in the same area, the person who registered or began using its mark first (i.e., the person with prior rights) will have superior legal rights to use its trademark.

Trade Secrets for Confidential Proprietary Information

Trade secret laws protect confidential proprietary business information that provides a competitive advantage over a business's competitors. Business information — such as formulas, practices, processes, designs, instruments, patterns, compilations of information, and other types of information - can be protected as a trade secret if the information is not generally known or reasonably ascertainable through permissible means (such as reverse engineering), is subject to reasonable efforts to maintain its secrecy, and provides actual or prospective economic advantage to its owner (WIPO, "What is a Trade Secret?," n.d.). Businesses often use a variety of practices to maintain the secrecy of their confidential proprietary information, such as restricting access to the information and requiring employees to sign confidentiality agreements.

A person who establishes trade secret rights in information has the legal right to prevent others from obtaining, using, or disclosing the information without the owner's consent. Moreover, trade secret rights continue to exist as long as the information remains secret, 
continues to be subject to reasonable efforts to maintain its secrecy, and continues to provide actual or prospective economic advantage to its owner.

For readers interested in more detailed descriptions and explanations of the different types of IP discussed above, there are several free resources available on the Internet from organizations like the World Intellectual Property Organization (WIPO) and the American Intellectual Property Law Association (AIPLA) (WIPO, "What is IP Law?," 2011; AIPLA, "What is Intellectual Property?," 2011).

\section{THE IMPORTANCE OF BEING EARNEST}

The critical second step in managing IP is understanding the critical times in the protection and enforcement of each type of IP. Each type of IP has its own procedure for obtaining and enforcing legal rights. Some types of IP_-like patents — can be created and protected only through a time-sensitive series of legal formalities, while other forms of IP — like copyright - require surprisingly few legal formalities to create and protect it.

Timing plays a critical role in the process for obtaining and enforcing rights in each type of IP. Creating and protecting intellectual property assets often requires taking just the right action at just the right time, every time, over time — or risk losing the asset entirely. The difficulty for businesspeople lies in the fact that the critical times for protecting and enforcing IP rights varies for each type of IP. To help clarify the issue for businesspeople, the following sections detail the critical times in the protection and enforcement of each type of IP.

Patents: The Early Bird Gets The Worm

Patents are by far the most time-sensitive type of intellectual property. The creation, protection, and enforcement of patent rights depend heavily on the timing of certain actions.

Timing is most critical in the application process for obtaining a patent. To receive a patent, as noted above, an invention must be novel and not obvious to a person skilled in the art 
of the invention. In most countries, an invention's novelty and obviousness are determined based on the state of the art that existed on the date that the patent application was filed, not on the date that the invention was invented. The U.S. currently awards patents based on the date of invention rather than the date of filing, but it will begin using filing dates to award patents beginning in March 2013 ("Leahy-Smith Act," n.d.). As a result, the timing of a patent application plays a critical role in determining if a patent application will be successful. The longer an inventor waits to file a patent application for his invention, the greater the risk that — by the time he does file a patent application — his invention will not be considered novel, or will seem obvious based on the technology in existence at that time.

Timing also plays a critical role in obtaining patents for an invention in multiple countries. As noted above, there is no "international patent" that provides protection for an invention in multiple countries. If the inventor wants patent protection for an invention in several countries, he must obtain a patent for the invention in each country. But international patent laws make it easier to obtain patents for the same invention in multiple countries.

Under the Paris Convention for the Protection of Industrial Property, a person who files a patent application for an invention in one country has a 12-month "priority period" during which it can file patent applications for the invention in other countries (WIPO, "Summary of the Paris Convention," n.d., para. 2). Any patent application filed during this "priority period" will be treated as if it were filed on the same date as the original patent application. This "priority period" gives an inventor up to one year to file patent applications for his invention in multiple countries without the risk that someone else can claim prior rights to his invention in a country by filing a patent application for the invention in that country before he is able to do so. The 
"priority period" also ensures that the obviousness of an invention will not be judged by technology that develops after the filing date of his original application.

Under the Patent Cooperation Treaty, inventors can take advantage of an international patent application system to file a single "international patent application" that can be used to obtain patents on an invention in multiple countries based on the filing date of the international application (WIPO, "Patent Cooperation Treaty," n.d.). When combined together, the Paris Convention and the Patent Cooperation Treaty provide an inventor a "priority period" of up to 30 months to obtain patents for an invention in multiple countries, while maintaining the priority filing date of its original application and avoiding the need to file separate patent applications in each country. But timing is critical for applicants who seek to take advantage of the priority period provided under international patent law: If an inventor fails to file an international patent application or other national patent applications within 12 months after filing its first patent application, the inventor cannot claim priority for its later applications based on the filing date of its original patent application.

Timing also plays a critical role in the disclosure of the invention and its effect on patentability. In some countries, an inventor can obtain a patent on an invention even if the invention has been disclosed to the public before the inventor applies for a patent, so long as the inventor file a patent application for the invention within the "grace period" provided by the nation's patent law. In the U.S., for example, an inventor is given a one-year "grace period" to file a patent application for an invention from the time the invention is first described in a publication anywhere in the world or first publicly used or sold in the U.S. In other countries, however, there is no "grace period," so an inventor cannot obtain a patent if his invention is publicly disclosed before the inventor files an application for a patent for the invention. In the 
European Union, for example, an inventor cannot obtain a patent on an invention that is publicly disclosed before the patent application is filed. To add to the difficulty, each country has its own rules about what constitutes public disclosure of an invention, including whether it applies to disclosures in foreign countries or only to disclosures inside the country. As a consequence, the timing of an invention's disclosure (as well as the nature and location) plays a critical role in the process for obtaining a patent, particularly where an inventor seeks to patent the same invention in multiple countries.

The end result of this complicated web of national and international patent laws is to place enormous importance on the timing for disclosing and seeking patent protection for an invention in the countries that are signatories to those international treaties. Even after the inventor has timely filed the necessary patent applications in the necessary countries, he must continue to meet critical deadlines that arise during the examination process if he is to navigate the patent application process successfully. In the end, timing plays a more critical role-in more important and varied ways - in the creation of patent rights than in the creation of any other type of IP.

Timing continues to play a role in managing patents, though in less critical ways, in the protection and enforcement of patent once they are obtained. Patent owners are required to pay maintenance or renewal fees to maintain their patents in many countries. In addition, even after a patent is granted, the patent owner may have to defend its patent against competitors' claims that it was improperly granted. Finally, the patent owner must be diligent in taking legal action against those who infringe his patent. Under the laws in most countries, a patent owner who unreasonably delays in taking action against a known infringer can lose the ability to enforce its rights against that infringer. In the U.S., for example, a patent owner can be barred from 
asserting his patent rights against an infringer if the patent owner waits more than six years after the infringement to bring legal action (“Time Limitation on Damages," 2011).

Trademarks: Strike Before the Iron Is Hot

Like patents, timing is critical in the creation of trademark rights because they are based on priority. In countries that recognize common law rights, the first person to use a trademark for particular goods and services in a particular geographic area acquires the legal right to prevent others from later using confusingly similar trademarks in the same area. In countries that permit or require national registration of trademarks, the first person to register a trademark for particular goods and services acquires the presumptive right to use the trademark for those goods and services anywhere in the country, and to prevent others from later using confusingly similar trademarks in any part of the country where the prior registrant uses its trademark. In disputes between parties using confusingly similar marks, the prevailing party is the one with prior rights in its mark (i.e., the party that was the first to establish rights in its trademark).

Timing has become an even more critical part of trademark law in recent decades with the advent of "intent-to-use" applications, which allow people to file applications to register trademarks that they have not even begun using yet. If the application proceeds to registration, the filing date of the application serves as the priority date that marks the beginning of the registrant's rights in the trademark (and not the date, at some later time, when the registrant actually begins using its trademark in commerce). Thus, in countries that allow such applications, disputes between parties claiming rights in conflicting trademarks are resolved in favor of the party with the earliest priority date for its trademark rights, based on the that it began using or filed an application to register its mark (whichever came first).

The role of timing in establishing trademark rights has taken on even greater significance with the creation of an international trademark registration system that is similar to the 
international patent system. The Paris Convention provides a six-month "priority period" for filing applications to register trademarks in multiple countries. After a person files an initial trademark application in his country of origin, the applicant has six months to file an application to register the same trademark for the same goods and services in other countries, which-if filed within the priority period — will be treated as if they were filed on the same date as the original application filed in the applicant's country of origin. During the six-month priority period after the filing of the original application in the country of origin, the applicant can also file an international trademark application through an international trademark application system known as the "Madrid System" ("Madrid System," n.d.). As with patents, the international trademark application system harmonizes and streamlines the process for filing applications for the same trademark in several different countries, which - if filed during the critical "priority period"will have the same priority date as the original application filed in the country of origin.

As a result of its emphasis on priority, the structure of national and international trademark law places extraordinary emphasis on timing — in using and/or applying to register a trademark - in the creation and enforcement of trademark rights. As a result, businesses that anticipate using a trademark in several countries are increasingly forced to develop multinational strategies for registering their trademarks to ensure that they will be able to use their trademarks in every country where they do business. Moreover, businesses are increasingly doing so even before they begin using their trademarks to ensure that a brand name that becomes popular in one country can be protected and used as a trademark in other countries as well, without the risk that others will beat them in the race to establish trademark rights to a popular brand name in a country. By striking before the brand is "hot," the original trademark owner can 
establish trademark rights and avoid problems later in the various countries where the brand name products or services are marketed.

Timing is also importance in maintaining a person's trademark rights. In countries that allow intent-to-use applications, the applicant has a limited period of time to begin using its mark after its application is approved for registration. In the U.S., for example, applicants have up to two years to begin using their mark after their application is approved for registration, but they must request successive six-month extensions of time after the initial six-month period.

Even after trademarks are registered, owners of registrations must file documentation and pay fees periodically to maintain and renew their registrations. In the U.S., for example, trademark registrants must file a declaration with the U.S. Patent and Trademark Office between the fifth and sixth year of registration to affirm that the trademark is still being used in U.S. commerce for the goods and services listed in the registration, and must renew their trademark registrations every ten years (USPTO, “Trademarks," n.d.). Other countries have similar maintenance and renewal requirements. In countries where registration is required to establish trademark rights, the failure to comply with these requirements results in the loss of any legal rights in the trademark. In the U.S., it results in the loss of the presumptive right to use the mark nationwide, leaving the trademark owner with only common law rights limited to the geographic scope of the trademark owner's existing use of its trademark.

Finally, as with patents, trademark owners must timely assert their rights against infringers or risk being barred from doing so. In the U.S., for example, a trademark owner who delays for up to three years before taking action against an infringer risks being prevented from asserting his rights against the infringer under on a legal doctrine known as laches (MachalFulks, n.d.). 


\section{Trade Secrets: An Ounce of Prevention Is Worth a Pound of Cure}

Trade secrets are among the least time-sensitive forms of IP. Legal protection exists the moment a business develops confidential proprietary information, so there are no legal formalities - no need to file an application or obtain a registration from the government, for example - to obtain trade secret rights. As a result, there are no deadlines for taking formal legal action that, if missed, could jeopardize a person's legal rights.

Despite the lack of legal formalities, there are still critical times when action is required to protect and enforce trade secrets. To protect trade secrets, a business must of course take steps to maintain the confidentiality of its information before it is disclosed, such as restricting access to information, marking materials as "confidential" or "trade secret," training employees regarding the handling of confidential information, and requiring employees and trade partners to sign confidentiality and non-compete agreements. These initial steps are critical because information loses trade secret protection once it becomes public. Some steps to protect trade secrets - like having employees sign agreements concerning ownership of confidential business information - must take place even before the creation of confidential proprietary information. In addition, a business must continue to use reasonable measures to maintain the secrecy of its trade secrets in order to continue enjoying trade secret protection of its information. A trade secret is good only as long as it is kept.

Timing is critical in the enforcement of trade secrets as well. Although there are no formal deadlines for taking legal action to enforce trade secrets, swift and certain action is often necessary — such as obtaining an injunction — to prevent further use or disclosure of the information. Trade secret owners that delay too long in taking legal action-typically 3-5 years, depending on the state - can be barred from enforcing their rights against someone who makes an unauthorized use or disclosure of its trade secrets (Citizen Media Law Project, n.d.). 
In the end, an ounce of prevention is worth a pound of cure when it comes to the protection of trade secrets. Ensuring trade secret protection for confidential information often requires significant planning, effort, and money. But the cost of maintaining the secrecy of confidential information often pales in comparison to the cost of trying to repair the damage once trade secret information is disclosed to others. Once confidential information becomes sufficiently "public," it ceases to be eligible for legal protection as a trade secret. In such cases, trade secret owners can still seek monetary damages against the party who publicly disclosed their trade secrets. But the true value of a trade secret may often be hard to quantify, and - even if it can be accurately measured - the defendant simply may not have the funds necessary to pay the cost. The most efficient and effective way to manage trade secret information is to ensure that it remains a trade secret.

\section{Copyright: A Stitch in Time Could Let You Recover Nine}

Unlike patents and trademarks, timing is less critical in copyright protection. Under international law, copyright protection is granted automatically when a work is created, so there are no legal formalities — such as filing an application or depositing a copy of the work with the government - required to create or preserve the copyright in one's work. As a result, there are no critical times when copyright owners must take action to obtain copyright in their works.

Although copyright exists from the moment a work is created, some countries require copyright owners to register their copyright with their national government before they can enforce their copyrights. In the U.S., for example, works that are created in the U.S. by U.S. citizens must be registered with the U.S. Copyright Office before the copyright owner can bring a lawsuit to enforce its copyright in U.S. courts (registration is not required for foreign works or works by foreign authors). U.S. copyright law also provides additional benefits to copyright owners who register their works, including the ability to recover statutory damages and 
attorney's fees from those who infringe the copyright in registered works (i.e., by copying the works without permission).

The timing of the copyright registration is seldom critical when it comes to enforcing the copyright in a work. In the U.S. and most other countries, for example, the copyright in a work can be registered even after an infringement occurs, without affecting the copyright owner's ability to enforce its copyright. But the timing of registration can be critical in obtaining certain legal remedies. In the U.S., for example, copyright owners can only recover statutory damages and attorney's fees against an infringer if the copyright in the work was registered before the infringement began, or within three months after the work was first made available to the public ("Registration as Prerequisite," 2011). In many cases, the economic feasibility of legal action to enforce one's copyright depends heavily, if not entirely, on the availability of these additional remedies. Given that statutory damages and attorney's fees are often significantly greater than the copyright owner's actual damages from infringement, registering the copyright in a work when it is first created could allow the copyright owner to recover many times what it otherwise would be able to claim. Thus, while not critical to establish legal rights, the timing of copyright registration is often critical to the success of efforts to enforce the copyright in a work.

Under the law in many countries, timing in the enforcement of copyright is only critical in cases where the copyright owner delays in taking action to enforce its rights. Copyright laws in most countries include statutes of limitations that prevent copyright owners from enforcing their rights against an infringer where the copyright owner fails to take legal action to enforce its rights for a period of time, typically three years. In the U.S., for example, a copyright owner can only file a lawsuit against someone who has infringed his copyright if the lawsuit is filed within three years after the infringement commenced ("Limitations on Actions," 2011). Even in such 
cases, copyright owners do not lose the copyrights in their works - they are merely prevented from enforcing their rights against that particular infringer based on that particular infringement. Indeed, copyright protection typically ends only when the period for protection has expired, or when the copyright owner has taken affirmative steps to waive the copyright in his work, thereby making the work freely available for public use.

For these reasons, copyright is among the most accessible, durable, and enduring forms of IP. Legal protection is easy to obtain and is seldom lost. It lasts far longer than any patent, and longer than most trademarks and trade secrets. In the end, for the reasons discussed above, timing is less critical in the protection and enforcement of copyright than for most other forms of IP. But in the U.S. at least, a stitch in time is worth nine when it comes to copyright: A little money spent registering the copyright in a work when it is first created could allow the copyright owner to recover many times that in statutory damages and attorney's fees at a later time.

\section{TIME TO WRAP UP}

As the foregoing discussion illustrates, timing plays a critical role in the protection and enforcement of IP. While the importance of timing varies among the different types of IP, the consequences for failing to take timely action can be severe no matter the type of IP. Understanding the identification and time-critical aspects of IP are the critical first steps to managing IP assets. At the very least, a basic understanding of these issues will allow businesspeople to know when to consult an attorney before it is too late. 


\section{$\underline{\text { Works Cited }}$}

American Intellectual Property Law Association (AIPLA). (n.d.). "What is IP Law?" Retrieved December 14, 2011, from http://www.aipla.org/about/iplaw/Pages/default.aspx.

Citizen Media Law Project. (n.d.). "Basics of a Trade Secret Claim.” Retrieved

December 16, 2011, from http://www.citmedialaw.org/legal-guide/basics-trade-secret-claim.

Interbrand. (2011). "Ranking of the Top 100 Brands." Retrieved December 17, 2011, from http:/interbrand.com/en/best-global-brands/best-global-brands-2008/best-global-brands2011.aspx.

Leahy-Smith America Invents Act. (n.d.). In Wikipedia. Retrieved December 18, 2011, from http://en.wikipedia.org/wiki/Leahy-Smith_America_Invents_Act.

Limitations on Actions. (2011). U.S. Code, Title 17, §507. Retrieved from http://www.law.cornell.edu/uscode/usc_sec_17_00000507----000-.html.

Machal-Fulks, Julie. (n.d.). “The Doctrine of Laches Can Make Trademark Enforcement a Tricky Business,” Intellectual Property Blog. Retrieved December 14, 2011, from http://www.scottandscottllp.com/main/doctrine_of_laches_trademark_enforcement.aspx.

Madrid System. (n.d.). In Wikipedia. Retrieved December 16, 2011, from http://en.wikipedia.org/wiki/Madrid_system.

Millman, Dan. (n.d.). As quoted on Thinkexist. Retrieved December 15, 2011, from http://thinkexist.com/quotation/i-learned-that-we-can-do-anything-but-we-can-t-do/373153.html.

Patentability of Inventions. (2011). U.S. Code, Title 35, § 101. Retrieved from http://www.law.cornell.edu/uscode/usc_sup_01_35_10_II_20_10.html.

Patents for Designs. (2011). U.S. Code, Title 35, § 171. Retrieved from http://www.law.cornell.edu/uscode/usc_sec_35_00000171----000-.html. 
Registration as Prerequisite to Certain Remedies for Infringement. (2011). U.S. Code, Title 17, § 412. Retrieved from http://www.law.cornell.edu/uscode/usc_sec_17_00000412---000-.html.

Stewart, Potter. (1964). Jacobellis v. Ohio (concurring opinion). Retrieved December 19, 2011, from http://www.law.cornell.edu/supct/html/historics/USSC_CR_0378_0184_ZC1.html.

Time Limitation on Damages. (2011). U.S. Code, Title 35, § 286. Retrieved from http://www.uspto.gov/web/offices/pac/mpep/documents/appxl_35_U_S_C_286.htm.

U.S. Copyright Office. (n.d.). "How Long Does Copyright Protection Last?" Retrieved December 20, 2011, from http://www.copyright.gov/help/faq/faq-duration.html\#duration.

U.S. Copyright Office. (2011). “Copyright Basics.” Retrieved January 18, 2012, from http://www.copyright.gov/circs/circ01.pdf.

U.S. Patent \& Trademark Office (USPTO). (n.d.). "Trademarks - keeping a registration alive.” Retrieved December 12, 2011, from http://www.uspto.gov/trademarks/process/maintain/prfaq.jsp.

U.S. Patent \& Trademark Office (USPTO). (n.d.). "Patents." Retrieved January 18, 2012, from http://www.uspto.gov/inventors/patents.jsp.

World Intellectual Property Organization (WIPO). (n.d.). "About Industrial Designs." Retrieved December 13, 2011, from http://www.wipo.int/hague/en/general/id_faq.html\#protect. World Intellectual Property Organization (WIPO). (n.d.). "About Trademarks." Retrieved December 13, 2011, from http://www.wipo.int/trademarks/en/about_trademarks.html\#function. 
World Intellectual Property Organization (WIPO). (n.d.). "Frequently Asked Questions.” Retrieved January 18, 2012, from http://www.wipo.int/copyright/en/faq/faqs.htm\#rights.

World Intellectual Property Organization (WIPO). (n.d.). “General Information on Copyright.” Retrieved December 14, 2011, from http://www.wipo.int/copyright/en/general/about_copyright.html.

World Intellectual Property Organization (WIPO). (n.d.). "Patent Cooperation Treaty." Retrieved January 18, 2012, from http://www.wipo.int/pct/en/treaty/about.html. World Intellectual Property Organization (WIPO). (n.d.). "Summary of the Paris Convention for the Protection of Industrial Property." Retrieved January 18, 2012, from http://www.wipo.int/treaties/en/ip/paris/summary_paris.html.

World Intellectual Property Organization (WIPO). (n.d.). "What is a Trade Secret?" Retrieved January 18, 2012, from http://www.wipo.int/sme/en/ip_business/trade_secrets/trade_secrets.htm.

World Intellectual Property Organization (WIPO). (2011). "What is Intellectual Property?" WIPO Publication No. 450(E). Retrieved December 14, 2011, from http://www.wipo.int/freepublications/en/intproperty/450/wipo_pub_450.pdf. 